IJLR: International Journal of Law Recontruction

Volume 5, Number 2, September 2021

DOI : http://dx.doi.org/10.26532/ijlr.v5i2.17923

\title{
THE REHABILITATION ON VICTIMS OF DRUGS ABUSE IN JUDICIAL DEVELOPMENT
}

\author{
Fatin Hamamah \\ Universitas 17 Agustus 1945 of Cirebon \\ fatinhamamah@untagcirebon.ac.id
}

\begin{abstract}
The drug abuse is increasingly prevalent in Indonesia. In connection with the problem of narcotics abuse, a criminal law policy is needed that positions narcotics addicts as victims, not perpetrators of crime. Implementation of rehabilitation is the realization of a rule, this is very important because with an implementation it can be known whether a rule has actually been implemented or not. The research method used is normative juridical, the results obtained state that the application of rehabilitation for Narcotics Abuse Victims is an effort to treat and recover Narcotics Addicts and Narcotics Abuse Victims carried out by the authorities in rehabilitation institutions. The rehabilitation stages for Narcotics Addicts and Victims of Narcotics Abuse are: 1) Initial Acceptance Stage, 2) Detoxification Stage, 3) Pre-Rehabilitation Stage, 4) Coaching and Guidance Stage, 5) Reintegration Stage, 6) Advanced Guidance Stage and 7) Stage Integration into Society.
\end{abstract}

Keywords: Abuse; Development; Drugs; Judicial; Rehabilitation; Victim.

\section{A. INTRODUCTION}

Narcotics affect the physical and mental. Narcotics when used in the right dosage and under the supervision of an anesthesiologist or psychiatrist can be used for treatment or research purposes so that they are useful for human physical and mental health. However, in Indonesia itself, narcotics distribution is misused, the use of narcotics is not for the benefit of human health or psychology but deviations from the actual function that can have a negative impact that will be very detrimental to the narcotics user. So the existence of the legislation that regulates it is very important. Narcotics not only make humans addicted, but can result in the death of a person quickly and unnaturally. Humans really need a clean place in their environment and a healthy body in order to carry on their life. Drug abuse has been called a crime against humanity. Narcotics are certainly the enemy of our nation in terms of printing the next generation of the nation that is healthy and free from narcotics. ${ }^{1}$

In Indonesia, narcotics are at an alarming level and can threaten the security and sovereignty of the state. Many cases are caused by narcotics cases. Areas that were previously untouched by narcotics trafficking gradually turned into centers for narcotics distribution. Likewise, children

1 Anton Sudanto, Penerapan Hukum Pidana Narkotika di Indonesia, ADIL: Jurnal Hukum Vol. 7 No.1 2017, page.131-161 
under the age of 21 , who should still be taboo about these illicit goods, have recently turned into addicts who are difficult to let go of. ${ }^{2}$

The abuse of narcotics, psychotropics, and other addictive substances has recently become increasingly prevalent in Indonesia. Narcotics according to Article 1 paragraph (1) of Act No. 35 of 2009 concerning Narcotics (Narcotics Law), are substances or drugs derived from plants or non-plants, both synthetic and semi-synthetic, which can cause a decrease or change in consciousness, loss of taste, reduce to eliminate pain, and can cause dependence. $^{3}$

Addicts are basically victims of narcotics abuse that violate government regulations, and they are Indonesian citizens who are expected to be able to build this country from adversity in almost all fields. ${ }^{4}$ In connection with the problem of narcotics abuse, a criminal law policy is needed that positions narcotics addicts as victims, not perpetrators of crime. Implementation of rehabilitation is the realization of a rule, this is very important because with an implementation it can be known whether a rule has actually been implemented or not. Act No. 35 of 2009 concerning narcotics has given different treatment to narcotics abusers, before this law came into effect there was no different treatment between users, dealers, dealers and narcotics producers.

In line with the increasing use of drugs, the government has tried to take firm action against syndicates and traffickers by giving severe punishments, even the death penalty. As for victims of users or addicts, the government has made efforts to reduce the adverse effects of drug use by providing rehabilitation facilities, both medically and socially. This is done so that victims of drug users can recover, become productive human beings, able to work to meet the needs of life and their families, and become a generation of a healthy and strong nation. ${ }^{5}$

However, the policy to place victims of drug users in rehabilitation facilities cannot work properly because they are still in conflict with the provisions of the Narcotics Law, in which case victims of drug users are still positioned as perpetrators of criminal acts, as a result they do not receive maximum treatment and recovery because should be in prison. Rehabilitation as an alternative to criminal sanctions (application of the ultimum remedium principle), this ultimum remedium principle is reflected in the provision of rehabilitation sanctions for drug abusers. The provision of criminal sanctions in the form of rehabilitation is not stipulated in the

2 Dikdik M. Arief dan Elisatris Gultom, Urgensi Perlindungan Korban Kejahatan, PT. Raja Grafindo Persada, Jakarta, 2013, page. 101

3 Wenda Hartanto, Penegakan Hukum Terhadap Kejahatan Narkotika Dan Obat-Obat Terlarang Dalam Era Perdagangan Bebas Internasional Yang Berdampak Pada Keamanan Dan Kedaulatan Negara, Jurnal legislasi Indonesia, Vol. 14 No. 01 March 2017, page. 1-16

4 Moh. Taufik Makarao, Suhasril, dan A.S., Moh. Zakky, Tindak Pidana Narkotika, Ghalia Indonesia, Jakarta, 2003, page. 74-75.

5 Parasian Simanungkalit Dewan, Model Pemidanaan Yang Ideal Bagi Korban Pengguna Narkoba di Indonesia, Yustisia Vol.1 No. 3 September-December 2012, page 80-93 
Criminal Code, but because narcotics problems are a special crime, the principle of lex specialist derogat lex generalis applies. ${ }^{6}$

In fact, if observed carefully, especially from a medical perspective, many experts argue that in fact individual drug users are victims of syndicates or links to illicit drug trafficking and trafficking which are difficult to escape from dependence. Even though these users may actually want to get out of the narcotics bondage that surrounds them, but because their nerves have been poisoned by the addictive substance, it is difficult to do so. Therefore, users or addicts require different treatment from patients in general.

Basically the circulation of narcotics in Indonesia is very wide. Act No. 35 of 2009 concerning Narcotics has given different treatment for perpetrators of narcotics abuse. Narcotics users or addicts as perpetrators of narcotics crimes are sentenced to imprisonment for narcotics abusers. Besides that, it can be said that narcotics addicts are victims, it is shown by the provision that narcotics addicts can be sentenced to rehabilitation. ${ }^{7}$

The role of rehabilitation in healing dependence for narcotics addicts is very important, because of the increasing number of narcotics addicts among children to adolescents. The effectiveness of rehabilitation to cure victims of narcotics is very necessary, considering the difficulty of victims or narcotics users to be able to be separated from drug dependence individually. Users or addicts of narcotics on the one hand are perpetrators of criminal acts, but on the other hand are victims. Every narcotics abuser who uses the criminal provisions is regulated in Article 127 of Act No. 35 of 2009 concerning Narcotics. Article 127 stipulates that every narcotics abuser is threatened with imprisonment, while narcotics addicts and victims of narcotics abusers are placed in medical rehabilitation and social rehabilitation institutions.

The purpose of this study is to find out and analyze the rehabilitation policy for victims of narcotics abuse is a solution in the development of criminal justice by using the point of view of justice in overcoming narcotics crime.

\section{B. RESEARCH METHODS}

The approach method used in this research is a normative juridical approach (normative legal research), namely normative juridical research is a scientific procedure to find the truth based on scientific logic from the normative side whose object is the law itself. ${ }^{8}$ So that normative legal research focuses on an inventory of positive law, legal principles and

6 Novita Sari, Penerapan Asas Ultimum remedium Dalam Penegakan Hukum Tindak Pidana Penyalahgunaan Narkotika, Jurnal Penelitian Hukum DE JURE, Vol 17, No. 3 2017, page.351-363.

7 Andri Winjaya Laksana, Tinjauan Hukum Pemidanaan Terhadap Pelaku Penyalahguna Narkotika Dengan Sistem Rehabilitasi, Jurnal Pembaharuan Hukum, Volume II No. 1 January-April 2015, page.74-85

8 Jhony Ibrahim, Teori Dan Metodologi Penelitian Hukum Normatif, Banyumedia, Malang, 2011, page.57. 
doctrines, legal findings in cases in concreto, legal systems, synchronization levels, legal comparisons and legal history. ${ }^{9}$

\section{RESULT AND DISCUSSION}

\section{Rehabilitation on Victims of Drugs Abuse In Judicial Development}

Narcotics abuse rehabilitation stage is the stage where Narcotics Addicts and Narcotics Abuse Victims get medical rehabilitation and social rehabilitation with several integrated treatment processes and integrated recovery carried out by rehabilitation institutions in order to free Narcotics Addicts and Narcotics Abuse Victims from Narcotics dependence and can carry out social function back in society. Act No. 35 of 2009 concerning Narcotics is the basis for law enforcement in order to ensure the availability of drugs for the benefit of science, technology, health and to prevent abuse and illicit trafficking of narcotics. ${ }^{10}$

The National Narcotics Agency contains a separate definition of rehabilitation, namely a process of recovering clients with drug use disorders, both in the short and long term, which aims to change behavior to restore the individual's function in society. ${ }^{11}$ The types of rehabilitation or the term rehabilitation in Act No. 35 of 2009 concerning Narcotics consist of 2 (two) namely:

a. Medical rehabilitation

An integrated process of treatment activities to free addicts from narcotics dependence, in accordance with Article 1 number 16 of Act No. 35 of 2009 concerning Narcotics. Various forms or methods in the implementation of the rehabilitation of drug users, in this case inmates who use drugs, such as medical rehabilitation, rehabilitation, but in the implementation of rehabilitation and medical methods are combined into one, so that at this stage the recovery process is four stages for drug users, namely the health examination stage. Doctor and nurse have a very important role in the initial examination of whether the patient / prisoner is in good health or not, the history of the disease that has been suffered and then all data on the physical characteristics of his health are recorded in the medical record. ${ }^{12}$

b. Social Rehabilitation

Social Rehabilitation is a process of integrated recovery activities both physically, mentally and socially so that former narcotic

9 Abdulkadir Muhammad, Hukum dan Penelitian Hukum. Cet. Ke-1, PT.Citra Aditya Bakti, Bandung, 2004, page.52.

10 Siswanto S, Politik Hukum Dalam Undang-Undang Narkotika, Rineka Cipta, Jakarta, 2012, page.83.

11 Ernawati, Heri Tahir, Rehabilitasi Sosial Terhadap Pecandu Narkoba Anak Dibawah Umur Di Yayasan Kelompok Peduli Penyalahgunaan Narkotika Dan Obat-Obatan Terlarang Makassar, Jurnal Tomalebbi, Volume IV, No. 2, June 2017, page.199-211

12 I Made Subantara, A. A. Sagung Laksmi Dewi, Luh Putu Suryani, Rehabilitasi Terhadap Korban Penyalahgunaan Narkotika di Badan Narkotika Nasional Provinsi Bali, Jurnal Preferensi Hukum, Vol. 1 No 1 July 2020 page. 243-248 
addicts can return to carrying out their social functions in community life. What is meant by ex-narcotics addicts here are people who have recovered from dependence on narcotics physically and psychologically. Social rehabilitation of ex-narcotics addicts can be carried out at social rehabilitation institutions appointed by the Minister of Social Affairs. Namely social rehabilitation institutions organized by both the government and the community. This rehabilitation measure is a repressive response, namely the response that is carried out after the occurrence of a crime, in this case narcotics, in the form of coaching or treating narcotics users. ${ }^{13}$

Regarding the rehabilitation problem that is applied, Article 57 of Act No. 35 of 2009 concerning Narcotics also explains, apart from social rehabilitation and rehabilitation, narcotics addicts and victims of narcotics abuse are also carried out by government agencies or the community through religious and traditional approaches. This means that religious and traditional approaches are also very important to be applied to narcotics addicts and victims of narcotics abuse, because everyone must have different religions and traditions and cannot be equated with one another. So that religious and traditional approaches can be adapted to the religion and traditions that exist in the tribe or society where narcotics addicts and victims of narcotics abuse live, while continuing to apply medical rehabilitation and social rehabilitation which have become obligations that must be carried out for narcotics addicts and victims of narcotics abuse.

Handling this rehabilitation is a stage where Narcotics Addicts and Victims of Narcotics Abuse get counseling and education from the authorities, so they can understand the dangers of Narcotics itself, and can recover from Narcotics dependence, and can return to carrying out social functions in society as well as the goals of Narcotics. The rehabilitation process itself for Narcotics Addicts and Victims of Narcotics Abuse. Narcotics rehabilitation is a process of recovering from the use of narcotics disorders, both in the short and long term, which aims to change behavior to restore the function of the individual to society. ${ }^{14}$

In terms of stages regarding rehabilitation, in this stage an extension and education are applied. Counseling here is about socializing the dangers of Narcotics itself to Narcotics Addicts and Victims of Narcotics Abuse. By cultivating a healthy and more productive life, Narcotics Addicts and Narcotics Abuse Victims can return to their normal lives as usual in society. While education here is about activities that can be done by Narcotics Addicts after the counseling is carried out. So that Narcotics Addicts and Narcotics Abuse Victims can change their lives with

13 Yuliana Yuli W, Atik Winanti, Upaya Rehabilitasi Terhadap Pecandu Narkotika Dalam Perspektif Hukum Pidana, ADIL: Jurnal Hukum, Vol.10 No.1 2019, page.136-149

14 Insan Firdaus, Analisa Kebijakan Optimalisasi Pelaksanaan Rehabilitasi Narkotika di Unit Pelayanan Teknis Pemasyarakatan, Jurnal IImiah Kebijakan Hukum, Vol 14, No 3 November 2020, page.469-492 
activities that are more beneficial for themselves, so they no longer need to deal with Narcotics, can make themselves better, become more successful in their fields which are certainly positive, and useful for families and the surrounding community.

In carrying out this stage of rehabilitation, there is guidance and supervision carried out by the authorities in this rehabilitation process. In the guidance and supervision, it is explained about the rules for the coaches and supervisors, namely the agency that oversees the medical rehabilitation and/or social rehabilitation institution conducts guidance to improve the capacity of the rehabilitation institution. The relevant agencies coordinate between Ministries or Institutions.

Regarding the issue of guaranteeing the quality of the implementation of medical rehabilitation and/or social rehabilitation, the Head of the agency that oversees the medical rehabilitation and/or social rehabilitation institution supervises the implementation of medical rehabilitation and/or social rehabilitation programs based on a Joint Regulation of the Chief Justice of the Supreme Court of the Republic of Indonesia, the Minister of Law and Human Rights. Human Rights of the Republic of Indonesia, Minister of Health of the Republic of Indonesia, Minister of Social Affairs of the Republic of Indonesia, Attorney General of the Republic of Indonesia, Head of Police of the Republic of Indonesia, and the National Narcotics Agency of the Republic of Indonesia in 2014 concerning Handling of Narcotics Addicts and Victims of Narcotics Abuse in Rehabilitation Institutions (State News RI Number 465 of 2014).

The treatment in the rehabilitation stage for Narcotics Addicts and Victims of Narcotics Abuse are:

a. Early Acceptance Stage

This is the stage of the examination to determine the diagnosis and treatment plan. The services provided include: interviews (can be done to families), physical examinations, psychological examinations, and laboratory examinations.

b. Detoxification Stage

Is the stage of eliminating toxins (drug effects) in the client's body. In this stage, medical therapy is dominant. In some community-based rehabilitation services, the common therapeutic modality is cold turkey, traditional, spiritual. At this stage, the addict is checked for his entire physical and mental health by a trained doctor. It is the doctor who decides whether the addict needs to be given certain drugs to reduce the withdrawal symptoms he is suffering from. Drug administration depends on the type of drug and the severity of withdrawal symptoms. In this case, doctors need sensitivity, experience, and expertise to detect the symptoms of drug addiction; ${ }^{15}$

15 Fauzi Rizky, Pelaksanaan Rehabilitasi Terhadap Pecandu, Penyalahguna dan Korban Narkotika, Riau Law Journal, Vol. 1 No.1, May 2017, page.102-123 
c. Pre-Rehabilitation Stage

This is the preparatory stage for the client to enter the next rehabilitation program. In this stage, testing (assessment), in the form of psychological tests, anamnesis, and individual counseling, which can support the diagnosis, prognosis, and action plan (treatment plan).

d. Coaching and Guidance Stage

The purpose of this stage is to change mal-addictive behavior into addictive behavior. The guidance includes physical, mental/psychological, social/spiritual guidance, through individual, group, and family counseling.

e. Reintegration Stage

The preparation stage before the client is returned to the family and community. In this stage, the client is involved in social activities and is directly involved with the community.

f. Advanced Guidance Stage

The client has returned to the home or community, and is still required to make contact with the relevant counselor as needed to monitor the progress of recovery.

g. Community Integration Stage

This is the final stage for the client after being considered able to stand alone and carry out his functions in the community without guidance.

After seeing the rehabilitation stage of Narcotics abuse, that the rehabilitation stage is an effort to process the treatment and recovery for Narcotics Addicts and Narcotics Abuse Victims carried out by the competent authorities in the rehabilitation institution to obtain the purpose of the rehabilitation so that Narcotics Addicts and Narcotics Abuse Victims can recover from narcotics dependence and can return to carrying out their functions in society, and not use Narcotics anymore. This stage is an effort in terms of handling rehabilitation for Narcotics Addicts and Narcotics Abuse Victims carried out by the Integrated Assessment Team for Narcotics Addicts and Narcotics Abuse Victims in order to recover from dependence on Narcotics itself. And a Narcotics Addict and Narcotics Abuse Victim can be said to have recovered if they have met the requirements given by the authorized institution.

Handling the rehabilitation is also an action taken by the authorities here that are helpful for Narcotics Addicts and Victims of Narcotics Abuse to free them from dependence on Narcotics itself and protect human resources from abuse and illicit traffickers of Narcotics, in order to recover from dependence on Narcotics itself. , so that they can live a better life and do not repeat their actions in terms of Narcotics Crimes.

The recovery of Narcotics Addicts and Victims of Narcotics Abuse is a goal of the rehabilitation process. Rehabilitation for addicts and victims of narcotics abuse is indeed expected to save the lives of addicts and victims of narcotics abuse themselves. So that the implementation of 
rehabilitation itself must be utilized as much as possible. ${ }^{16}$ Narcotics addicts must meet several benchmarks in terms of being able to say they have recovered from the narcotics themselves, regarding the benefits of rehabilitation decisions in Narcotics Crimes, namely not using Narcotics anymore (Drugs Free), meaning that narcotics addicts and victims of narcotics abuse are free from Narcotics substances and don't take it anymore. Then the next step is not to commit a crime (Criminalize Free), meaning that Narcotics Addicts and Narcotics Abuse Victims who have recovered are no longer committing criminal acts related to Narcotics crime.

Observing developments in several countries, a new paradigm has emerged in viewing narcotics users/addicts who are no longer viewed as evil behavior (criminals) but as people with chronic diseases who must receive treatment and recovery gradually. This paradigm then creates a new policy in dealing with victims of narcotics users who are no longer legally processed, but immediately take users/addicts to a rehabilitation center. In other words, this paradigm leads to efforts to decriminalize narcotics users. The application of criminal law in the form of imprisonment for victims of narcotics users has proven unsuccessful, in fact, the number of victims of narcotics users who are sentenced to imprisonment is increasing every year. This is what needs to be reviewed regarding the purpose and function of implementing criminal law for victims of narcotics users.

The Narcotics Law does not provide a definition of a rehabilitation sentence. But in general and based on developing practice, a rehabilitation sentence can be defined as a verdict in a narcotics crime case handed down by a judge in the form of placing the defendant in a medical rehabilitation institution or social rehabilitation for a certain period of time, in which the rehabilitation period is counted as serving a sentence. This rehabilitation verdict can only appear in a situation where an addict or narcotics user is in a criminal justice process or simply means that the addict or narcotics user has committed a narcotic crime. ${ }^{17}$

The most important factor in efforts to overcome narcotics abuse, which is often ignored, especially by law enforcement officers in Indonesia, is the existence of rehabilitation efforts. The model of punishment for victims of narcotics users until now still places them as criminals (criminals), so that rehabilitative efforts are often neglected. ${ }^{18}$

\section{Rehabilitation Of Legal Development In Criminal Law Policy}

Narcotics addicts and abusers are "self-victimizing victims", namely victims of crimes committed by themselves. Because addicts and

16 Ibrahim Fikma Edrisy, Implementasi Rehabilitasi Terhadap Anak Penyalah Guna Narkotika, Fiat Justisia Journal of Law, Vol 10 Issue 2, April-June 2016, page.317-340

17 Donny Michael, Implementasi Undang-Undang Narkotika Ditinjau Dari Perspektif Hak Asasi Manusia, Jurnal Penelitian De Jure, Vol. 18 No. 3, September 2018, page.415-432

18 Siti Hidayatun, Yeni Widowaty, Konsep Rehabilitasi Bagi Pengguna Narkotika yang Berkeadilan, Jurnal penegakan hukum dan keadilan Vol. 1 No. 2, September 2020, page.166-181 
narcotics abusers experience dependence (addiction) as a result of themselves abusing narcotics. However, addicts and abusers should get protection so that they recover from this dependence (addiction).

The Double Track System is a two-track system regarding sanctions in criminal law, namely having types of criminal sanctions and action sanctions. The focus of criminal sanctions is shown on wrongdoing that has been done by someone through the imposition of suffering so that the person concerned becomes a deterrent. The focus of action sanctions is more focused on efforts to provide assistance to the perpetrator so that he changes. Criminal sanctions place more emphasis on retaliation, while action sanctions come from the basic idea of protecting the community and fostering or caring for the perpetrator. ${ }^{19}$

Appropriate crime prevention efforts should not only focus on various matters relating to the causes of crime but what methods are effectively used in crime prevention. ${ }^{20}$ Policies in the prevention and eradication of narcotics crime are part of legal politics. The policy is a comprehensive effort in realizing a healthy young generation in order to improve the welfare of the community. This is in line with the opinion of Soehardjo Sastrosoehardjo in Wisnubroto and Widiatama that: "Legal politics does not stop after the issuance of the Act, but it is precisely here that problems begin to arise. Both those that have been estimated or calculated from the start as well as other problems that arise unexpectedly. Each Law requires a long period of time to conclude how far the legal political objectives of the Law can be achieved. If the results are estimated to be difficult to achieve, is it necessary to make changes or adjustments as necessary. ${ }^{21}$

The policy of overcoming the crime of narcotics abuse cannot be separated from the State's goal to protect the entire Indonesian nation and to promote public welfare based on Pancasila and the 1945 Constitution. As a citizen, it is obligatory to pay attention to educational services through the development of knowledge. On the other hand, the government's attention to security and public order, especially those that have an impact on disturbances and acts of narcotics criminals. Policies taken in tackling narcotics aim to protect the community itself from the dangers of narcotics abuse.

The process of medical and social rehabilitation, one form of legal protection for addicts and narcotics abusers, is mandatory reporting as regulated in Government Regulation Number 25 of 2011 concerning the Implementation of Compulsory Reporting of Narcotics Addicts. Compulsory reporting is self-reporting activities carried out by narcotic addicts who are old enough or their families, and/or parents or guardians of narcotic addicts who are not old enough to report to the Recipient

19 Sujono, A.R, dan Bony Daniel, Komentar dan Pembahasan Undang-Undang No. 35 Tahun 2009 tentang Narkotika, Sinar Grafika, Jakarta, 2011, page.23.

20 Ibid.

21 A.L. Wisnubroto dan G. Widiatana, Pembaharuan Hukum Acara Pidana, Citra Aditya Bakti, Bandung, 2005, page.10. 
Institution for Compulsory Reporting (IPWL) to receive treatment and/or treatment through medical rehabilitation. and social rehabilitation. Recipient of Reporting Recipient Institutions are public health centers, hospitals, and/or medical rehabilitation institutions and social rehabilitation institutions appointed by the government.

There are provisions that can lead to confusion in the Narcotics law, especially in terms of rehabilitation for users. In the provisions contained in the Narcotics Law it is stated that every addict is obliged to undergo rehabilitation, but in the subsequent provisions it is stated that the procedures that must be passed in the rehabilitation stage must obtain the consent of the victim concerned. These are 2 (two) contradictory things because in general addicts will not give their consent to undergo rehabilitation. ${ }^{22}$

The effectiveness of rehabilitation to cure victims of narcotics is very necessary, considering the difficulty of victims or narcotics users to be able to be separated from drug dependence individually. Narcotics users or addicts on the one hand are perpetrators of criminal acts, but on the other hand are victims. ${ }^{23}$ Providing rehabilitation for narcotics abusers is considered necessary to suppress the use of narcotics and illegal drugs. Given the current number of children as victims of drug abuse continues to increase. Although in this case children are often said to be victims, but still in the legislation it is said to be a crime. ${ }^{24}$

Policy in the context of repressive response to victims of narcotics abuse with rehabilitation is a very appropriate step in realizing the value of justice. The relationship between rehabilitation measures and the Criminal Law Policy will be seen whether the rehabilitation measures can support crime prevention policies. This means that the rehabilitation of narcotics addicts does not only need to be seen from the perspective of criminal law reform, but must be seen from a broader perspective, including being seen from the perspective of criminal policy, because criminal law reform is part of criminal policy. ${ }^{25}$

The basis of the perspective of restorative justice is that the concept of crime is an act that violates the rights of individuals (ie victims of crime), in addition to violating society, the state and the interests of the violators themselves. Thus, every violation of criminal law, there are actually 4 (four) related interests, namely the person whose rights are violated (victims of crime), the community, the state, and the offender himself. People whose rights are violated (victims of crime) are the first

22 Harris Y. P. Sibuea, Kedudukan Pengguna Narkotika Dan Kesiapan Fasilitas Rehabilitasi Bagi Penyalahguna Narkotika Berdasarkan Undang-Undang No. 35 Tahun 2009 Tentang Narkotika, Negara Hukum, Vol. 6, No. 1, June 2015, page.45-63

23 Kusno Adi, Op.Cit. page.3

24 Dina Novitasari, Rehabilitasi Terhadap Terhadap Anak Korban Penyalahgunaan Narkoba, Jurnal Hukum Khaira Ummah, Vol. 12. No. 4 December 2017, page.917-926

25 Arie Kartika, Madiasa Ablisar, Marlina, Edy Ikhsan, Aplikasi Kebijakan Hukum Pidana Terhadap Pelaksanaan Rehabilitasi Pecandu Dalam Tindak Pidana Narkotika (Studi Di Rehabilitasi Kementerian Sosial Pamardi Putra "INSYAF" Sumatera Utara), USU Law Journal, Vol.3.No.1 April 2015, page. 44-55 
to be interested, therefore the criminal justice system must access these four interests by placing the interests of victims of crime as the main interests because the purpose of criminal justice is to resolve conflicts (conflict resolution) that occur as a result of criminal law violations, then the role of the state in the system is reduced and vice versa the empowerment of the role of victims of crime and society on the one hand and offenders on the other. ${ }^{26}$ Victims of drug abuse can be called victims of crime, for that it is necessary to provide solutions in law enforcement for narcotics abusers.

\section{CONCLUSION}

The implementation of rehabilitation for Narcotics Addicts and Victims of Narcotics Abuse is an effort of the treatment and recovery process for Narcotics Addicts and Narcotics Abuse Victims carried out by the competent authorities in rehabilitation institutions. The rehabilitation stages for Narcotics Addicts and Victims of Narcotics Abuse are: 1) Initial Acceptance Stage, 2) Detoxification Stage, 3) Pre-Rehabilitation Stage, 4) Coaching and Guidance Stage, 5) Reintegration Stage, 6) Advanced Guidance Stage and 7) Stage Integration into Society. The effectiveness of rehabilitation in judicial development plays a very important role in overcoming victims of narcotics abuse in Indonesia.

\section{BLIBIOGRAPHY}

\section{Books:}

Abdulkadir Muhammad, 2004, Hukum dan Penelitian Hukum. Cet. Ke-1, PT.Citra Aditya Bakti, Bandung;

A.L. Wisnubroto dan G. Widiatana, 2005, Pembaharuan Hukum Acara Pidana, Citra Aditya Bakti, Bandung;

Dikdik M. Arief dan Elisatris Gultom, 2013, Urgensi Perlindungan Korban Kejahatan, PT. Raja Grafindo Persada, Jakarta;

Jhony Ibrahim, 2011, Teori Dan Metodologi Penelitian Hukum Normatif, Banyumedia, Malang;

Moh. Taufik Makarao, Suhasril, dan A.S., Moh. Zakky, 2003, Tindak Pidana Narkotika, Ghalia Indonesia, Jakarta;

Rena Yulia, 2010, Viktimologi Perlindungan Hukum Terhadap Korban Kejahatan, Graha Ilmu, Yogyakarta;

Siswanto S, 2012, Politik Hukum Dalam Undang-Undang Narkotika, Rineka Cipta, Jakarta;

26 Rena Yulia, Viktimologi Perlindungan Hukum Terhadap Korban Kejahatan, Graha Ilmu, Yogyakarta, 2010, page. 177. 
Sujono, A.R, dan Bony Daniel, 2011, Komentar dan Pembahasan UndangUndang No. 35 Tahun 2009 tentang Narkotika, Sinar Grafika, Jakarta;

\section{Journals:}

Andri Winjaya Laksana, Tinjauan Hukum Pemidanaan Terhadap Pelaku Penyalahguna Narkotika Dengan Sistem Rehabilitasi, Jurnal Pembaharuan Hukum, Volume II No. 1 January-April 2015;

Anton Sudanto, Penerapan Hukum Pidana Narkotika di Indonesia, ADIL: Jurnal Hukum Vol. 7 No.1 2017;

Arie Kartika, Madiasa Ablisar, Marlina, Edy Ikhsan, Aplikasi Kebijakan Hukum Pidana Terhadap Pelaksanaan Rehabilitasi Pecandu Dalam Tindak Pidana Narkotika (Studi Di Rehabilitasi Kementerian Sosial Pamardi Putra "INSYAF" Sumatera Utara), USU Law Journal, Vol.3.No.1 April 2015;

Dina Novitasari, Rehabilitasi Terhadap Terhadap Anak Korban Penyalahgunaan Narkoba, Jurnal Hukum Khaira Ummah, Vol. 12. No. 4 December 2017;

Donny Michael, Implementasi Undang-Undang Narkotika Ditinjau Dari Perspektif Hak Asasi Manusia, Jurnal Penelitian De Jure, Vol. 18 No. 3, September 2018;

Ernawati, Heri Tahir, Rehabilitasi Sosial Terhadap Pecandu Narkoba Anak Dibawah Umur Di Yayasan Kelompok Peduli Penyalahgunaan Narkotika Dan Obat-Obatan Terlarang Makassar, Jurnal Tomalebbi, Volume IV, No. 2, June 2017;

Fauzi Rizky, Pelaksanaan Rehabilitasi Terhadap Pecandu, Penyalahguna dan Korban Narkotika, Riau Law Journal, Vol. 1 No.1, May 2017;

Harris Y. P. Sibuea, Kedudukan Pengguna Narkotika Dan Kesiapan Fasilitas Rehabilitasi Bagi Penyalahguna Narkotika Berdasarkan UndangUndang No. 35 Tahun 2009 Tentang Narkotika, Negara Hukum, Vol. 6, No. 1, June 2015;

Ibrahim Fikma Edrisy, Implementasi Rehabilitasi Terhadap Anak Penyalah Guna Narkotika, Fiat Justisia Journal of Law, Vol 10 Issue 2, April-June 2016;

I Made Subantara, A. A. Sagung Laksmi Dewi, Luh Putu Suryani, Rehabilitasi Terhadap Korban Penyalahgunaan Narkotika di Badan Narkotika Nasional Provinsi Bali, Jurnal Preferensi Hukum, Vol. 1 No 1 July 2020;

Insan Firdaus, Analisa Kebijakan Optimalisasi Pelaksanaan Rehabilitasi Narkotika di Unit Pelayanan Teknis Pemasyarakatan, Jurnal Ilmiah Kebijakan Hukum, Vol 14, No 3 November 2020; 
Parasian Simanungkalit Dewan, Model Pemidanaan Yang Ideal Bagi Korban Pengguna Narkoba di Indonesia, Yustisia Vol.1 No. 3 SeptemberDecember 2012;

Novita Sari, Penerapan Asas Ultimum remedium Dalam Penegakan Hukum Tindak Pidana Penyalahgunaan Narkotika, Jurnal Penelitian Hukum DE JURE, Vol 17, No. 3 2017;

Siti Hidayatun, Yeni Widowaty, Konsep Rehabilitasi Bagi Pengguna Narkotika yang Berkeadilan, Jurnal penegakan hukum dan keadilan Vol. 1 No. 2, September 2020;

Wenda Hartanto, Penegakan Hukum Terhadap Kejahatan Narkotika Dan ObatObat Terlarang Dalam Era Perdagangan Bebas Internasional Yang Berdampak Pada Keamanan Dan Kedaulatan Negara, Jurnal legislasi Indonesia, Vol. 14 No. 01 March 2017;

Yuliana Yuli W, Atik Winanti, Upaya Rehabilitasi Terhadap Pecandu Narkotika Dalam Perspektif Hukum Pidana, ADIL: Jurnal Hukum, Vol.10 No.1 2019. 